

\section{Service quality in a higher education context: an integrated model}

\author{
Parves Sultan \\ School of Management and Marketing, Central Queensland University, \\ Rockhampton, Australia, and \\ Ho Yin Wong
}

Deakin Graduate School of Business, Deakin University, Melbourne, Australia

\section{Service quality}

Received 23 September 2011

Revised 25 July 2012

Accepted 26 July 2012

\begin{abstract}
Purpose - The aim of this study is to develop and empirically test an integrated model incorporating the antecedents and consequences of service quality in a higher education context.

Design/methodology/approach - This research employed both qualitative and quantitative research methods. The data from three focus groups, conducted at the Central Queensland University (CQU), Rockhampton, Australia, generated key themes and their interrelationships. The theoretical model was then tested using structural equation modelling technique on a sample of 528 university students.

Findings - The findings show that information (marketing communications) is more statistically significant than past experience as the antecedents of service quality. The consequences of service quality are composed of trust, satisfaction, and image. Overall, the results suggest a good validity of the theoretical model and the key paths in the model are found statistically significant, except past experience affecting service quality.

Originality/value - The model provides a good explanation of a university brand image, and perceived service quality was found playing an important role in this model. Universities intending to enhance their image are encouraged to consider focusing their efforts on marketing communication information, service quality, student satisfaction and trust.
\end{abstract}

Keywords Service quality, Past experience, Communication, Image, Satisfaction, Trust, Higher education, Brands, Customer services quality

Paper type Research paper

\section{Introduction}

A marketing approach to examine students' perceptions of service quality in the context of higher education may improve service functions, and attract and retain students. Students look for evidence of quality of services when making an uncertain and high risk decision of choosing a university (Angell et al., 2008; Donaldson and McNicholas, 2004). Ignoring the nature and importance of service quality may not be advantageous for universities in the higher education industry.

Australian higher education institutions are some of the popular destinations for students. However, the Bradley report published in December 2008 states that there is a clear sign that the quality of the educational experience is declining. One of the significant recommendations of this study emphasises course experience as perceived by the students (Bradley et al., 2008).

The authors wish to thank the Editor(s) and the reviewers for their valuable comments.

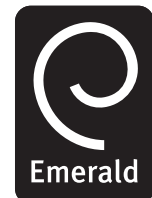

Asia Pacific Journal of Marketing and Logistics

Vol. 24 No. 5,2012 pp. $755-784$ (C) Emerald Group Publishing Limited 1355-5855 DOI 10.1108/13555851211278196 
APJML 24,5

756

Higher education is a pure service that requires greater amount of interpersonal contact. As higher education provision is a service and students are expected to fund their educational expenses, it seems appropriate that universities make a shift from being product-led, i.e. relying on the product to sell, towards a more customer-led approach (Angell et al., 2008). The customer-centric approach (or student-centred approach) of service quality in educational literature has gained momentum as the increasing cost of education has created a new generation of students with greater awareness than ever before (Stodnick and Rogers, 2008). This approach could also result in improving quality within a higher education context.

A number of studies in service quality of higher education (Brown and Mazzarol, 2009; Chitty and Soutar, 2004; Martensen et al., 2000) have empirically examined the applicability of the European customer satisfaction index (ECSI) model, an integrated model developed to measure customer satisfaction in the commercial service sector. The ECSI model considers "corporate image" as a built-in variable, and indicates that corporate image is an antecedent to expectation and service quality. While corporate image is built over the years accumulating customers' (and stakeholders') satisfaction and trust, considering corporate image as an antecedent variable may provide little managerial implications when the goal is to build corporate image in a highly competitive market. Although the ECSI model and its instruments are developed based on the commercial service sectors, its applicability in value-based higher education sector needs careful examination.

Improving service quality within a higher education context is often mentioned as an internal goal without any explicit references to what is meant by service quality in higher education. Discussing better quality without defining what it is, how it is perceived by students, what are the antecedents and consequences of quality improvements, how it can be improved and enhanced is of little value. Thus, the aim of this paper is to understand the role of service quality and its antecedents and consequences in an Australian higher education context. More specifically, this study shows the image formation process, in the context of a university, as one of the consequences of service quality evaluation mediated through student satisfaction and student trust. The empirical findings in this study shed light on what affects service quality and how perceived service quality affects institutional image. Policy makers in the higher education industry can make use of the findings to strengthen their universities' image by reinforcing marketing communications, service quality, and student satisfaction and trust.

\section{Literature review}

Service quality: the critical measures and the integrated models

The current studies develop a number of measures of service quality in commercial service settings. Of these service quality measures most of the studies have used either the SERVQUAL (perception-minus-expectation) measure (Parasuraman et al., 1985, 1988) or the SERVPERF (perception-only) measure (Cronin and Taylor, 1992, 1994). Empirical studies on service quality in terms of relative superiority between the SERVQUAL scale and the SERVPERF scale have been examined. On the one hand, studies find that the SERVPERF scale is a better alternative than the SERVQUAL scale (Babakus and Boller, 1992; Brady et al., 2002; Brown et al., 1993; Jain and Gupta, 2004; Zhou, 2004). On the other hand, the SERVQUAL has received much attention as a 
measure of service quality (Chebat et al., 1995; Furrer et al., 2000; Zeithaml and Bitner, 2003). However, one study (Carrillat et al., 2007) states that both the SERVQUAL and the SERVPERF scales have received more than 46 per cent of total citations in service quality literature between 2002 and 2007. Thus, the effectiveness of the SERVQUAL and the SERVPERF scales is often contingent upon the nature and objective of a study.

Although there are debates in relation to superiority of these service quality measures, the SERVPERF measure of service quality has been termed as an effective measure for the purpose of explaining variance in dependent constructs (Cronin et al., 2000; Parasuraman et al., 1994; Zeithaml et al., 1996). For example, one cross-sectional study reported that the SERVPERF approach is a superior measure to the SERVQUAL approach in explaining and predicting the overall degree of students' satisfaction (Li and Kaye, 1998). A similar finding is also evident in another longitudinal study (Dabholkar et al., 2000). Dabholkar et al. (2000) use three measures, namely the SERVPERF measure; measured disconfirmation, i.e. explicit comparisons are made in the instruments after the service is received; and computed disconfirmation, i.e. expectations (before the service experience)-minus-perceptions (after the service experience). The findings state that the SERVPERF measure is superior over computed disconfirmation and measured disconfirmation. The study recommends that if the objective of the study is to predict service quality or to gauge its determinants, the SERVPERF measure should be used rather than disconfirmation. In other words, the SERVPERF measure is more appropriate to use in developing an integrated model and explaining causal relationships. Therefore, the present research is centred upon the SERVPERF measure.

The SERVPERF measure has been used in the current studies to develop and examine a number of integrated models including the Swedish customer satisfaction barometer (SCSB) (Fornell, 1992), the American customer satisfaction index (ACSI) model (Fornell et al., 1996), and the ECSI model (Cassel and Eklöf, 2001). In contrast, the Norwegian customer satisfaction barometer (NCSB) (Johnson et al., 2001) is conceptualised on the SERVQUAL perspective. The key focus of attention in these models is to determine the extent of customer satisfaction across national level industries.

\section{Service quality measures in higher education context}

Service quality research has been extended to the higher education domain. The current literature attempts to measure functional performances of educational services either following the SERVQUAL or the SERVPERF measures. Appendix 1 shows 15 research studies that followed these measures in order to find the key aspects or dimensions of service quality in various country contexts. These studies are published in the last 14 years. The findings of these studies suggest that dimensions of higher education service quality vary widely in the context of culture, university and even school or department. One of the reasons for this is that student perception is shaped by culture, previous interaction, and experience and marketing communication messages. Dimensions of higher education service quality also vary because of manipulation of research instruments (Stodnick and Rogers, 2008; Angell et al., 2008).

\section{Service quality models in higher education context}

Higher education institutions are service organisations (Hennig-Thurau et al., 2001; Joseph and Joseph, 1997; Sultan and Wong, 2010a). The concept of relationship 
APJML 24,5

758 marketing is of high importance in services marketing, especially, the services that require high-contact and long-term contact to get an outcome. Maintaining relationships with tertiary students in a higher education environment can produce long-term benefit to the university.

Several studies have attempted to develop and examine integrated models in the context of higher education. Appendix 2 provides summarised findings of major studies that examined integrated models in the context of higher education. In short, students' satisfaction and students' loyalty have been the centre and the final outcome, respectively, in most of these integrated service quality models in the context of higher education. Service quality has been found to be the critical determinant of perceived satisfaction in the context of higher education. While service quality is a form of attitude and a long-run overall evaluation, satisfaction is a transaction specific measure (Bitner, 1990; Bolton and Drew, 1991; Cronin et al., 2000; Cronin and Taylor, 1992). Thus, the extant studies state that these are two distinct constructs (Cronin and Taylor, 1992; Parasuraman et al., 1988), and that perceived service quality is the determinant of satisfaction (Carlson and O'Cass, 2010; Gounaris et al., 2010). While perceived quality is found to be the determinant of satisfaction, the current service quality literature in higher education context is inadequate to explain the determinant(s) of perceived quality.

In the context of higher education, the relationships between some of the constructs in the ECSI model are negative and insignificant. For example, the findings of the ECSI model in the context of Portuguese's higher education (Alves and Raposo, 2007) show that expectation and satisfaction has a negative significant relationship. In the context of Australian higher education, Brown and Mazzarol (2009) find that image, value, satisfaction and loyalty have chain effects, and other relationships in the ECSI model are insignificant, weak and indeterminate paths. The other important aspect of these studies (Alves and Raposo, 2007; Brown and Mazzarol, 2009) and in the ECSI model (Cassel and Eklöf, 2001) is that the image construct has been conceptualised as the determinant of perceived quality and expectation. Research also demonstrates that customer satisfaction and image affects loyalty in the context of the hotel industry (Kandampully and Suhartanto, 2000). These studies conceptualise corporate image as a built-in variable and assume that it is built only by means of marketing communications. However, in a process model it is essential to show how image (corporate/brand image) is built and what affects image. Grönroos (1984) states that corporate image is built mainly by technical quality and functional quality. Corporate image has been modelled as an outcome variable of perceived quality, value and satisfaction in the context of commercial service sectors (Johnson et al., 2001; Nguyen and LeBlanc, 1998). The image as an outcome variable reflects both the degree to which consumption experience, perceived value and satisfaction enhance image and their interrelationships over the time.

The image of a university in a competitive global market is important because it determines the marketability of the programs/courses, and affects student attraction, retention and funding opportunities. The current literature is inadequate to explain the image formation processes in the context of higher education sector. As a result, the current studies suggest for a separate framework and methodology for studying students' perceptions of higher education services (Chitty and Soutar, 2004; Gallifa and Batalle, 2010; Sultan and Wong, 2010a, b). In particular, Gallifa and Batalle (2010, p. 157) stated that: 
Discovering student perceptions of quality may be a quest for any centre, university or university systems [...]. Questions of interest include: what are the framework, appropriate strategy, and methodology for approaching the purpose?

Therefore, "there is a quest for a comprehensive model especially in the higher education sector" (Sultan and Wong, 2010b, p. 266).

In summary, the present study is conceptualised on the SERVPERF measure, and thus the ECSI model is an appropriate model as the point of departure. In this context, the present study addresses several gaps. First, the study examines the antecedents of perceived service quality and their relationships with perceived service quality. Second, it examines the outcomes of perceived quality evaluation, where institutional image has been modelled as the final consequence. Subsequently, this study develops an integrated service quality model in the context of a university.

\section{Development of research framework and conceptual hypotheses \\ The relationship between information and service quality}

Information pertaining to service quality is important as it provides a basis for evaluating service quality attributes during service encounters. Students receive information about quality aspects from a number of marketing communication sources. In this respect, Rowley (1997) states that customers look for clues (before purchasing), including, for example, advertisements and word-of-mouth from the physical environment about the organisation's capabilities and quality in terms of provision of services. Studies ascribed that formal communications from various sources, including advertisements, leaflets, and related articles in magazines and newspapers, affect the way customers interpret ambiguous evidence concerning quality (Deighton, 1984; Devlin et al., 2002; Mathews, 1994). Adequate information accelerates consumers' learning in terms of attributes of the product or service. This suggests that the role of providing adequate and reliable information to the students, prior to their enrolment, can have tremendous effects in shaping their perception about service quality of a university. In short, perceived quality is affected by reliable information. Therefore:

H1. Information received by the students positively affects their perception of service quality in a higher education context.

\section{The relationship between past experience and service quality}

Information alone cannot provide a complete view of the world around us. To get a complete view about a particular phenomenon, one needs to integrate his/her imagination and experience along with information (Blythe, 1997; O'Neill and Palmer, 2003). Past experience provides a brief cognitive standard and helps in evaluating the standard of service quality of present and/or future service encounters. Trials of a product may be seen as an important part of individuals' learning since it provides evidence (through experience) that affects the evaluation of product performance (Biedenbach and Marell, 2010). When customers accumulate negative experience, they evaluate perceived quality negatively (Hoch and Deighton, 1989). In other words, consumers' perception of service quality is influenced by the degree of prior experience (O'Neill and Palmer, 2003). In the context of higher education, past experience of receiving education service may provide a basis for evaluating educational service quality of a potential university. Students' recent experience with staff of the university 


\section{APJML 24,5}

\section{0}

may also provide a basis for forming service quality perceptions of a potential university. Therefore:

H2. The past experience of the students positively affects perception of service quality in a higher education context.

\section{The relationship between service quality and satisfaction}

The concept of satisfaction occupies a central position in marketing thought and practice. The extant studies suggest that the critical determinant of perceived satisfaction is perceived quality (Carlson and O'Cass, 2010; Cronin et al., 2000; Eskildsen et al., 2004; Fornell et al., 1996; Gounaris et al., 2010). This is because both perceived quality and satisfaction are attitude driven. Perceived quality is a long-run overall evaluation and satisfaction is the outcome of overall evaluation. In the context of higher education, one study finds that service quality affects satisfaction through perceived value (Brown and Mazzarol, 2009). However, another study examines service quality-satisfaction relationship using the ECSI model, and finds that service quality directly affects satisfaction (Alves and Raposo, 2007). This suggests that the students are satisfied if service attributes perform well. Therefore:

H3. Perception of service quality positively affects students' satisfaction in a higher education context.

\section{The relationship between service quality and trust}

Service quality and trust have been viewed as the centre of relationship marketing (Berry, 2002). The process by which an individual attributes trust is based on his/her experience with that brand (Delgado-Ballester and Munuera-Aleman, 2001). While evaluation of service quality is an experiential norm, trust is an emotional norm. Consumers' positive attitudes towards a brand lead him/her to believe that the brand is capable of providing satisfaction, which prolongs consumers' understanding, faith and feeling that they would get a similar outcome in any future transaction. Thus, trust is a belief and confidence that the service performance and subsequent satisfaction will be identical in future.

Students' trust, in the context of higher education, is identified as one of the major consequences of service quality evaluation in the context of graduated and dropout students of four German universities (Hennig-Thurau et al., 2001). This is because evaluation of service performance often provides belief and confidence about the possible outcome of future service encounter. While higher education institutions are trying to increase student numbers each year, the trust of enrolled students and past students may play a vital role in increasing the marketability of the university's programs and the brand itself. In addition, a number of studies stated that a long-term approach to control marketing costs in an increasingly competitive environment can be done through building student trust in their institution (Ghosh et al., 2001; Sumaedi et al., 2012). This is because students' trust determines the relationship strength between students and their university. Thus, institutional integrity and reliable service performance build students' beliefs and confidence which in turn determines students' trust. Therefore:

H4. Perception of service quality positively affects trust in a higher education context. 
The relationship between satisfaction and image

People develop knowledge systems (i.e. schemas) to interpret their perception of the company image (Andreassen and Lindestad, 1998). Image formation procedure is cognitive in the sense that ideas and feelings about previous experiences and satisfaction with an organisation are stored in memory and transformed into meaning based on stored categories (Nguyen and LeBlanc, 1998; Johnson et al., 2001). Thus, a company could have many images representing the experiences and feelings of the public (Dowling, 1993; Liew, 1997).

Customer satisfaction is a judgement of a specific service encounter (Bolton and Drew, 1991; Cronin and Taylor, 1992). In the context of Mauritian hotel guests, one study finds that customer satisfaction has a positive and significant effect on corporate image (Hu et al., 2009). This is because the level of satisfaction derived from each service encounter is viewed as having an effect on image assessments (Nguyen and LeBlanc, 1998). Thus, image may derive from overall transactional outcome and consumers' subsequent emotion (e.g. satisfaction). Student satisfaction creates a halo effect on the institutional image. When students are satisfied, their attitudes toward the university are improved. This attitude then affects the image. Thus, corporate (or institutional) image is the accumulated attitude derived as a result of satisfaction. Therefore:

H5. Students' satisfaction positively affects university image in a higher education context.

\section{The relationship between trust and image}

The corporate image is an impression stakeholders have about an organisation. Several authors stated that image is not what the company believes it to be, but the feelings and beliefs about the company that exist in the market and which arise from experience and observation of relevant stakeholders (Bernstein, 1984; Abratt, 1989). This indicates that corporate image is not in-built for an organisation; rather it is built overtime with much effort and investment. In this context, Liew (1997) suggested that public confidence and trust could be helpful for successful management of corporate image. Thus, one of the primary determinants of corporate image is confidence and trust, which results from experiencing high quality services and satisfaction (Johnson et al., 2001; Nguyen and LeBlanc, 1998).

Student perception of university image is important as it summarises students' insights of the standing of a university in the market. Since university image is a guide to and a simple way for a student to evaluate its programs, services offered and overall value in the market, it is important to know whether student trust contributes towards university image. Students develop cumulative effects of trust over the years with their academic and administrative staff and with their institution. Their cumulative trust develops thorough cognitive impressions and builds a positive image about the university. Therefore:

H6. Students' trust positively affects university image in a higher education context.

\section{The research model}

Figure 1 shows the research model. It is a process model because it shows the antecedents of perceived quality and how perceived quality affects satisfaction,

\section{Service quality}

761 
APJML 24,5

762 trust and institutional image. The model shows that students consider several factors that affect their perception of service quality prior to service experience (pre-experience, at time $t-1$ ). During service experience (i.e. at time $t$ ), they evaluate service attributes and develop attitudes toward service attributes/aspects. The post-experience of service quality (i.e. at time $t+1$ ) results in several cognitive (or emotional) understandings, which in turn result in institutional image.

\section{The research methodology}

The present study adopts methodological triangulation, where both qualitative and quantitative research methods were employed. Methodological triangulation has been receiving growing interest in marketing research for its contribution to knowledge development (Dahlstrom et al., 2008; Freling and Forbes, 2005; Stavros and Westberg, 2009). The major benefit of incorporating both approaches into the research methodology is that the weakness of one approach is compensated for by the strengths of the other (Deshpande, 1983).

\section{Qualitative research method}

This research employed a focus group technique because this technique provides flexibility, direct interaction, large amount of data, and is user friendly, easy to understand, and time and cost saving (Stewart et al., 2007). Although there is no rule of thumb about the number of members in a focus group, one study suggested that "a group consisting of 5-10 respondents is appropriate" (Krueger and Casey, 2000, p. 10). Literature suggests that several (three to four) groups are convened depending on distinct population segments (Morgan, 1988; Stewart et al., 2007). In this research, three focus group discussions were held with nineteen students studying at the Central Queensland University (CQU), Rockhampton, Australia using convenience and purposive sampling techniques following the suggestions of the current studies (Babbie, 2007; Brown et al., 2009; Gatfield et al., 1999; Oldfield and Baron, 2000; Punch, 2005). Appendix 3 shows the demographic profiles of these students.

The content analyses procedures were followed to analyse the focus group data. The reasons for doing so were to identify:

(1) key themes relevant to the antecedents;

(2) dimensions of perceived service quality;

(3) key themes relevant to the consequences of service quality;

\begin{tabular}{|l|l|l|}
\hline Pre-experience (at time $t-1)$ & During experience (at time $t)$ & Post-experience (at time $t+1)$ \\
\hline
\end{tabular}

Figure 1.

The research model

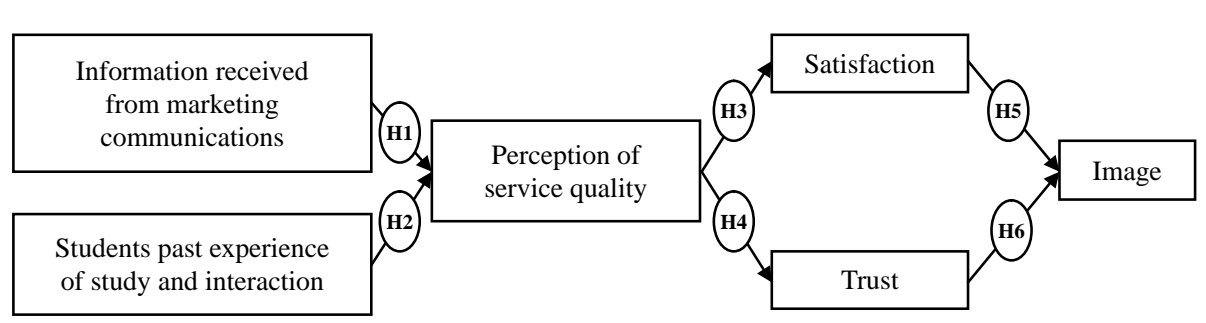


(4) interrelationships between themes; and

(5) items to measure these themes following the suggestions of the extant studies (Krippendorff, 2004; Neuendorf, 2005; Sarantakos, 1997).

The findings from the qualitative research method were used to strengthen the conceptual model.

\section{Quantitative research method}

The scale development process followed the suggestion of Churchill (1979), and included 59 items in the final survey. The final survey instrument design excluded two items of information, three items of past experience and four items of service quality after pilot testing. The excluded items had cross-loadings and low loadings. These were validated through expert opinion. The expert panel included two senior academics experienced in qualitative and quantitative research methods in marketing and one senior practitioner from the marketing division, CQU.

An online click-through survey link was sent to the CQU students who were studying at one of its ten campuses in Australia. Thus, a random technique was adopted (Bryman and Bell, 2007; Bethlehem, 2010). The online questionnaire is methodologically and financially appealing to those who study and work with student populations. An online survey increases the likelihood of participation and its processing fees are usually lower than those for paper surveys (Sax et al., 2003). The layout design of the online survey questionnaire followed the suggestions of Dillman et al. (2009).

A total of 1,032 responses were received (7 per cent of the student population). It has been stated that the web-based survey receives a low response rate (Sax et al., 2003). Although due to "required completion answer" constraint there was no missing data, the incomplete cases and the cases having less than six months of studying experience were deleted. This resulted to 528 usable questionnaires.

The data was analysed statistically including mean, standard deviation, skewness and kurtosis, and sample differences using non-parametric $\chi^{2}$ test in order to get an overview of the collected data set. The next stage was the establishment of valid and reliable scales for each of the constructs, and to examine their causal relationships. The process of construct validation followed the suggestions of the current literature (Hair et al., 2010; O'Leary-Kelly and Vokurka, 1998). The analysis of the measurement model used item parcels or a "partial disaggregation" method. The purpose of item parcelling or partial disaggregation is to distil the original set of scale items to a reduced number of indicators that are empirically balanced measures of the construct (Landis et al., 2000). Literature suggests that item parcelling can be used when the ratio of sample size to estimated parameters is 5:1 or above (Bentler and Chou, 1987). This ratio for the present study is 528:48 or 11:1.

There are several advantages of using item parcelling technique. First, item parcels are more reliable than individual items, have more scale points, and are more likely to have linear relations with each other and with other factors (Little et al., 2002). Second, it provides more normal distribution of data than individual items (Bruin, 2004). Third, it provides more stable parameter estimates, reduce idiosyncratic characteristics of items and simplify model interpretation (Hau and Marsh, 2004). Fourth, the use of item parcelling results in the estimation of fewer model parameters, and this results in a more optimal variable to sample size ratio and more stable parameter estimates (Bandalos, 2002).
Service quality

763 
APJML 24,5

764
For the purpose of this study, the item parcelling technique included two composites for each of the latent constructs. This is because a latent construct with single indicator can be problematic (Hall et al., 1999). As a result, each latent construct in the present study, followed by unidimensionality and other relevant tests, formed two composites. Specifically, composite one contained the highest loading and lowest loading, composite two contained the next highest loading and next lowest loading, and this procedure continued until the end item which belongs to either composite one or composite two. If there were an odd number of items, the extra item was added to composite two. Both the measurement model and the structural model used the fit indices as suggested by several studies (Hair et al., 2010; Ho, 2006).

\section{Operationalisation of the constructs}

Operationalisation of information and past experience constructs is based on focus group findings. The other constructs, including, service quality, satisfaction, trust and image, are operationalised based on literature review and focus group findings.

Information. Information is defined as explicit and implicit messages that students receive directly and indirectly from the university before enrolment. This construct included three items from focus group data.

Past experience. Past experience is defined as customers' experience with the service organisation and service personnel (Devlin et al., 2002; Zeithaml et al., 1993). The present study defines past experience as students' previous educational experience before enrolling at the university, previous experience of service encounter with the university, their interaction and relationships with staff and/or the university prior to enrolment, and subsequent treatment provided by the university. This construct included three items from focus group data.

Perceived service quality. Service quality is defined as the totality of features and characteristics of a product or service that bears on its ability to satisfy stated or implied needs (Johnson and Winchell, 1988). Perceived service quality is a cognitive process of quality assessment, meaning that service quality assessment is a psychological result of perception, learning, reasoning and understanding of the service attributes. The perceived service quality construct includes 26 items.

Satisfaction. Student satisfaction is a psychological state of happiness resulting from performance evaluation of the service attributes in the context of higher education. In this respect, two items are adapted from Cronin et al.'s (2000) study and five items are developed from the focus group findings.

Trust. Trust is a belief and confidence that the service performance and subsequent satisfaction will be identical in future. In the context of higher education, student trust refers to their belief and confidence in the university's integrity and reliable service performance (Rojas-Méndez et al., 2009). The trust construct includes 12 items. Of these, eight items are adapted from the extant literature (Chaudhuri and Holbrook, 2001; Delgado-Ballester and Munuera-Aleman, 2005; Horppu et al., 2008; Lau and Lee, 2000; Sultan and Wong, 2010a; Zboja and Voorkees, 2006) and four items are developed from the focus group findings.

Image. The image of an organisation is the profile or sum of impressions and expectations in the minds of individuals (Topalian, 1984). The corporate image is the experiences, beliefs, feelings, knowledge and impressions, that people have about a company (Abratt, 1989). Thus, it is an aggregate process by which consumers compare 
and contrast various companies (LeBlanc and Nguyen, 1996) and form an impression about those companies based on their experience, beliefs and feelings. The image construct includes four items from the literature (Andreassen and Lindestad, 1998; Martensen et al., 2000; Nguyen and Leblanc, 2001), and four items are developed from the focus group findings.

In summary, this study used 59 items, of which 33 items are adapted from current literature and 26 items are developed from the focus group findings.

\section{Results}

\section{Qualitative findings}

The relationship between information and service quality. The focus groups were asked to discuss the factors that affect the perception of the quality of services in terms of their university prior to enrolment. Respondents stated that information affects the level of quality judgment. They also underlined that the information provided by the institution has to be true, satisfy wants and be reliable. For example, one of the focus group participants states that:

[...] if the product is new and there is no set standard, in that case, the level of quality in terms of my needs would be very much influenced by whatever product-related promotional materials are being discharged by the supplier (Respondent No. 17).

This particular quote implies that assessment of quality depends on information available in promotional materials.

The relationship between past experience and service quality. The focus group findings reveal that students' past experience also affects service quality. In this context, one of the focus group participants states that:

[... . before coming to this university, I had only high school experience. From that point, it is hard to say, but at least it tells [...] that we would learn some advanced stuff at the university (Respondent No. 5).

The other participant states that:

I've attended three [...] universities [...]. Many people would agree that out of these three [...]. University is the prestigious. But why I didn't go back to that university? Thus, considering location, proximity and recent experience with staff, I am keep going with this University (Respondent No. 13).

These quotes state that students' recent experience with the university and staff could have an impact on perceived quality.

The relationship between service quality and satisfaction. The focus group findings reveal that satisfaction is one of the important consequences of perceived service quality. For example, one of the focus group respondents, in this connection, states that:

[...] if someone is not satisfied with the performance of the university, he has to finish his degree. He can't just be in the middle of no way and do nothing (Respondent No. 7).

Another specific focus group quote states that:

$[\ldots]$ everyone says $[\ldots]$ and $[\ldots]$ are big and better universities in $[\ldots]$ comparative to this University [... . but to me this university fulfils my need. I have never found anything lacking. I have access to the resources that I need (Respondent No. 5).

This suggests that the students are satisfied if service attributes perform well. 


\section{APJML 24,5}

\section{6}

The relationship between service quality and trust. Students' positive attitudes towards a university could lead him/her to believe that the university is capable of providing services in future, which in turn, refers to student trust. In this context, one focus group member states that "[...] if the university provides quality services the obvious outcome is our satisfaction and the next is our understanding that the University can satisfy us in future" (Respondent No. 3). This suggests that student trust is contingent upon service performance.

The relationship between satisfaction and image. The focus group findings reveal that student satisfaction affect institutional image. For example, one of the focus group participants states that "I think that the image of the university plays a vital role in that our satisfaction builds a cumulative image of the university" (Respondent No. 4). The other participant states that "[. . . ] the employers never see whether you have High Distinction or Distinction. What they see is which university you have attended" (Respondent No. 11). The both quotes suggest that student satisfaction has a cumulative effect on institutional image, and that institutional image plays a vital role amongst students when choosing a university.

The relationship between trust and image. The focus group finding suggests that student trust has an effect on institutional image. In this connection, one specific quote states that "[...] the University claims that the graduates of this University receive high pay in Australia. As a student, I believe it is true" (Respondent No. 2). Student trust is a belief and confidence that any future interaction with the university will be identical and positive. This in turn develops a thorough impression about their university. Overall, the qualitative findings support the theoretical model and its hypotheses.

\section{Quantitative findings}

An overview of the descriptive statistics and sample differences. A brief overview of the sample profile is meaningful for validating the findings. The total number of usable responses was 528, of these 389 responses were from females and 139 responses were from males. The average age of this sample was 20 . The findings also show that there were 259 students studying full time, 223 students studying part time, and 46 students were identified as other category including distance/flex (external) students. Of these respondents, 3.60 per cent were enrolled in short courses, 5.50 per cent were enrolled in diploma programs, 75.20 per cent were enrolled in undergraduate programs, 12.50 per cent were enrolled in masters program and 3.20 per cent were enrolled in doctoral research program. In terms of course/program of study, 22 per cent students were from business studies program, 6.60 per cent students from information technology, 11 per cent students from engineering and applied sciences, 22.30 per cent students from health sciences, 2.30 per cent students from pure sciences, 16.50 per cent students from arts and social sciences, and 19.30 per cent students from other programs including education, learning management, public administration, environment and design, hospitality and tourism, accounting, social works, property, and music and communication.

The mean statistics for each of the items were between 4.07 and 7, meaning that respondents exceed "neutral" position and there is a tendency towards "agree" zone (i.e. between 5 and 7). The standard deviation varies between 1.00 and 1.32 . This is because the data for each of the variables were collected on a seven-point Likert-type scale and students rated their attitude between 1 (strongly disagree) and 7 (strongly agree). Another reason for such dispersion is that the students were 
having various nationalities, various modes of study (i.e. full time, part time, flexible), levels of study (i.e. short course, diploma, undergraduate, masters, doctoral), and levels of maturity (aged between 17 and 70). However, none of the values of the items with regard to skewness and kurtosis are extreme (i.e. greater than \pm 1 ).

The non-parametric $\chi^{2}$ test of goodness-of-fit for gender shows that the $\chi^{2}$ value is insignificant, $\chi^{2}(\mathrm{df}=1, n=528)=0.02, \quad p<0.86$, meaning that there is no significant difference in the proportion of male and female identified in the current sample as compared with the student population of the CQU. Similar results are also evident in terms of "Location of Study" and "Program of Study" variables. For example, the $\chi^{2}$ tests' results for location of study and program of study were: $\chi^{2}(\mathrm{df}=10, n=528)=1.32, p<0.99$ and $\chi^{2}(\mathrm{df}=6, n=528)=0.01, p<1.0$, respectively.

Exploratory factor analysis and reliability test results. The exploratory factor analysis (EFA) with principal component analysis and varimax rotation method was conducted. Table I shows the results of the EFA, reliability test, Kaiser-Mayer-Olkin (KMO) measure of sampling adequacy and other relevant test results. The EFA results for each of the constructs revealed a single factor solution except service quality. The EFA results for service quality showed a three factor solution, namely, academic service quality (ACSQ), administrative service quality (ADSQ) and facilities service quality (FSQ). The KMO test result is above 0.50 (De Vaus, 2001) and the $p$-value of the Bartlett's test of sphericity is less than 0.05 . These results suggest that these constructs were suitable for factor analysis. The Cronbach's $\alpha$ coefficient for each of the constructs were greater than 0.70, suggesting a good reliability (De Vaus, 2001; Hair et al., 2010; Ho, 2006). Overall, the EFA results were satisfactory for each of the scales.

Convergent validity test results. The convergent validity shows that the items are uniquely measuring their respective constructs as hypothesised. This study used three approaches. First, the factor loadings of the individual items for their respective constructs were substantial (i.e. minimum 0.5 or higher, and ideally 0.7 or higher) (Hair et al., 2010). However, it was evident that one item of FSQ (SQ_15) and one item of ADSQ (SQ 12) have 0.44 and 0.40 loadings. These two items were incorporated as these were close to 0.5 and derived from focus group findings. Second, the critical ratio values were greater than 1.96 and these are significant at the 0.05 level in the confirmatory factor analysis results. These suggest strong convergent validity (Wong and Merrilees, 2007). Third, the average variance extracted (AVE) was computed for each of the latent constructs using the square root of total variance explained found through EFA. The results showed that in every case the AVE was greater than 50 per cent (or 0.5), suggesting good convergent validity for each of the constructs (Hair et al., 2010). Overall, the three approaches used to measure convergent validity were satisfactory.

Discriminant validity test results. The discriminant validity shows that one construct is uniquely different from other constructs in the model. Three approaches were adopted to ensure discriminant validity. First, there were eight constructs that formed 28 pairs. Thus, pairwise $\chi^{2}$ difference tests at a time were performed for discriminant validity checks using AMOS. The results showed that the $\chi^{2}$ difference for each of the pairs had been significant ( $p$-value $<0.01$ ). Thus, the results suggested the existence of discriminant validity. Second, the AVE estimate and the squared correlation estimate were compared. The discriminant validity exists when AVE estimate is greater than the squared correlation estimate between pairs of factors 


\section{APJML \\ 24,5}

768

Table I.

EFA, reliability test and other test results

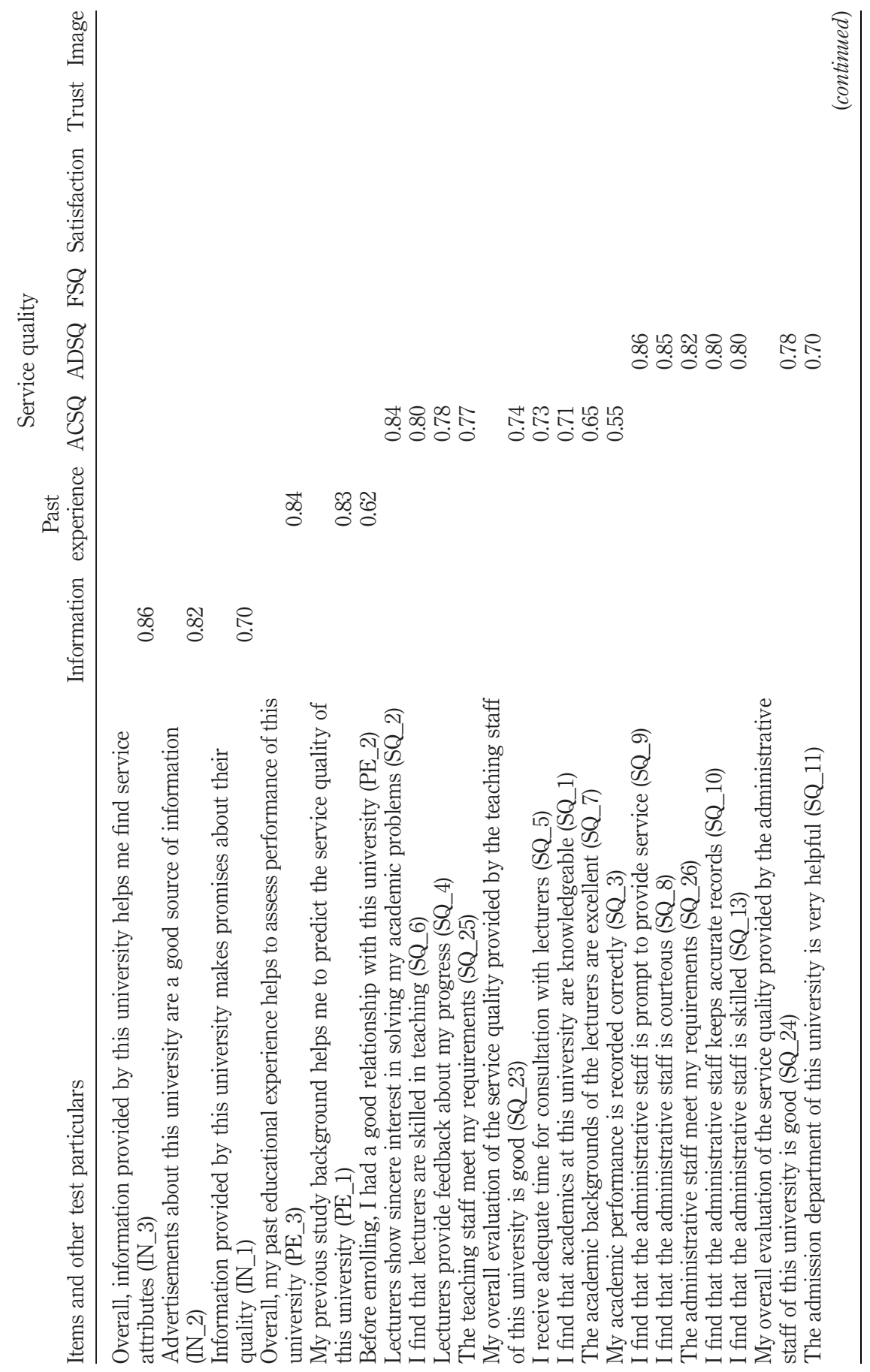




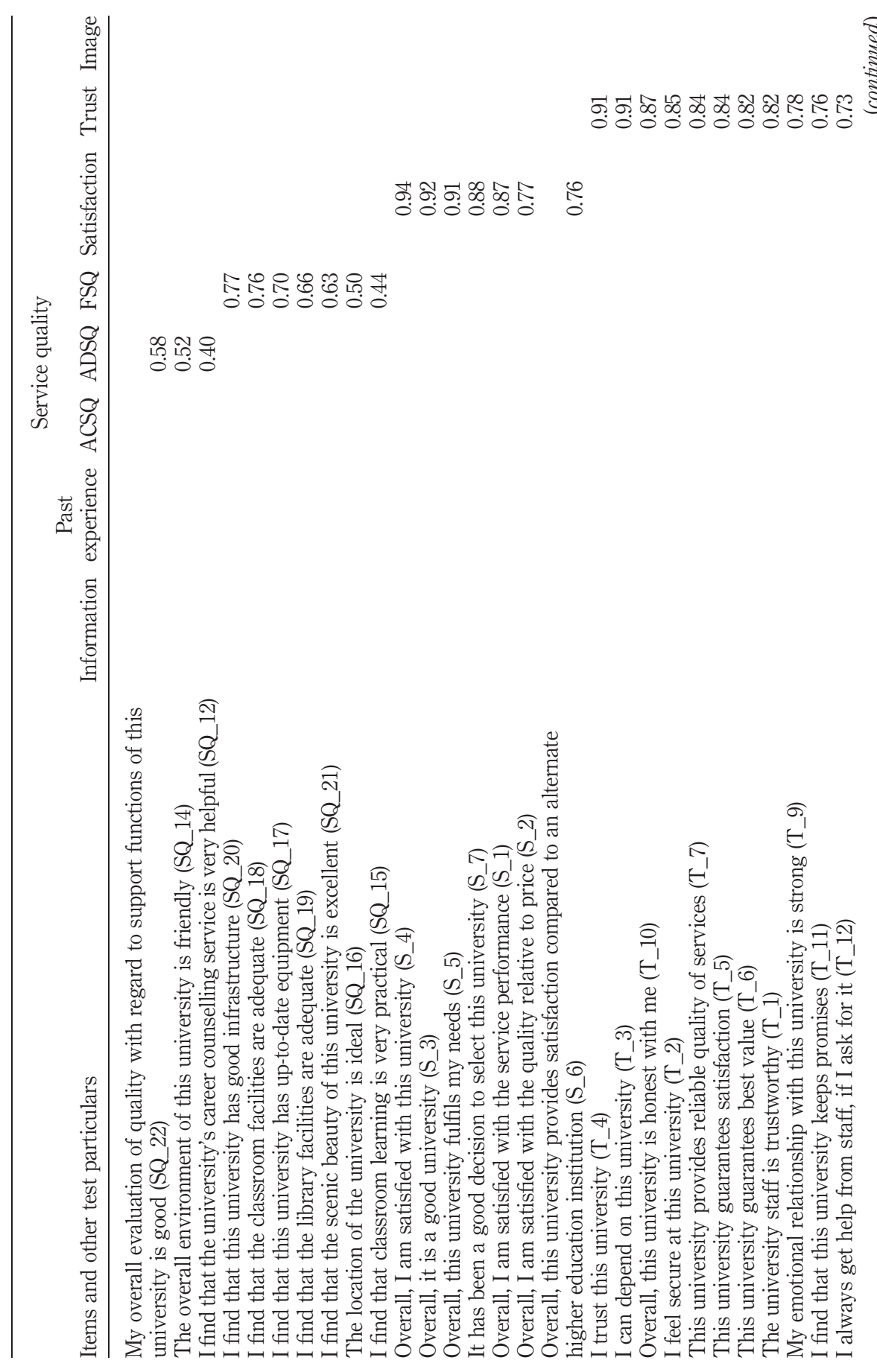

Service quality

769

Table I. 
APJML

24,5

770

Table I.

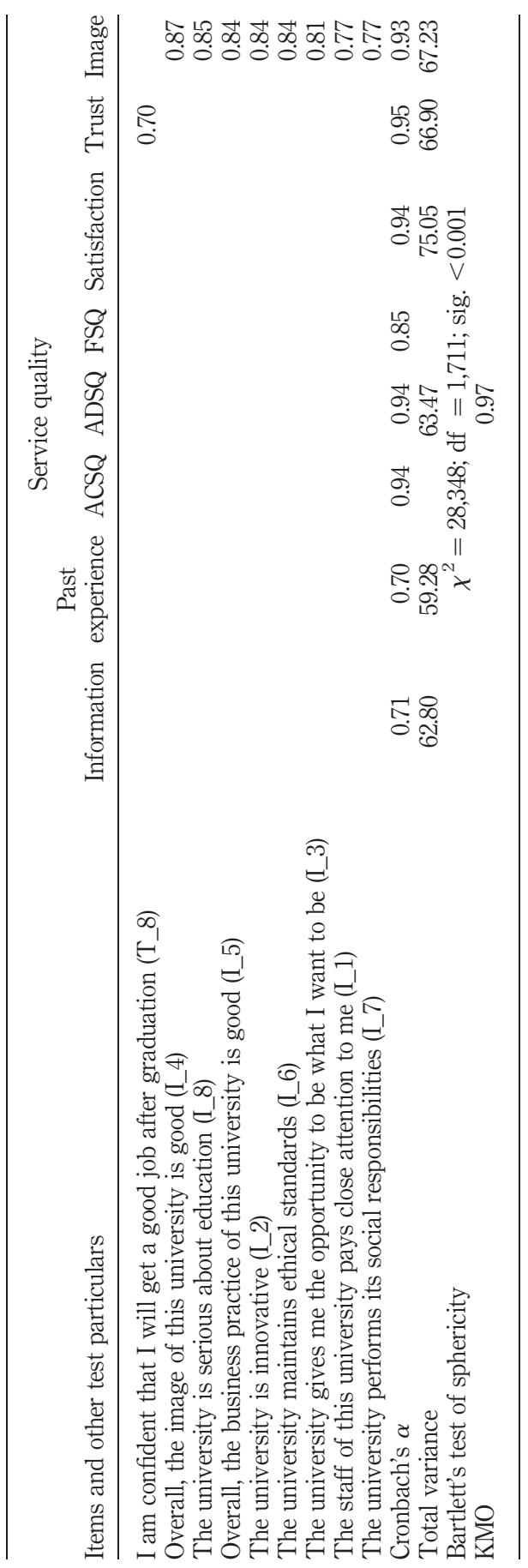


(Fornell and Larcker, 1981; Hair et al., 2010; Wong and Merrilees, 2007). The upper diagonal of Table II represents the AVE and the lower diagonal represents the squared correlation estimate. The results show that in every respect the estimated AVE for each pair of construct is greater than the squared correlation estimate for that pair. Thus, discriminant validity is established. Third, the 28 pairs entered (pairwise items) for EFA using principal components with varimax rotation in order to examine if each of these pairs produce two components exactly. The results showed that each time there were always two components with their respective items. Thus, this provides further confidence in discriminant validity. Overall, these three approaches demonstrated satisfactory discriminant validity.

Results of the measurement model analyses. The measurement model within the CFA framework tests all the latent variables and their respective indicators at one time. It shows how constructs are operationalised by sets of measured variables (Hair et al., 2010). The results show that the $\chi^{2}$ statistic is significant, $\chi^{2}(n=528, \mathrm{df}=76)$ is $129.70, p<0.01$, though not desirable. This was, perhaps, due to the size of the samples considered for this study $\left(n=528\right.$, greater than 200). Studies suggest that significant $\chi^{2}$ can occur due to large samples (Anderson and Gerbing, 1988; Hair et al., 2010; Ho, 2006). However, the alternative measures to the $\chi^{2}$ value show satisfactory results. For example, first, the results of Hoelter's critical $n$ of the present study is 396 at the 0.05 level and 438 at the 0.01 level. In both of these cases, Hoelter values exceeds 200 (Hoelter, 1983), meaning that the model achieves its acceptance at the 0.05 and 0.01 level if the largest samples are 396 and 438, respectively. Second, the normed $\chi^{2}$ is a ratio between $\chi^{2}$ and degrees of freedom. The accepted norm of $\chi^{2} / \mathrm{df}$ is 3.0 or less (Hair et al., 2010). The normed $\chi^{2}$ of the measurement model is 1.7 that indicates a reasonable model fit when considering the sample size effect. The SRMR value of the measurement model is 0.02 . As a rule of thumb, an SRMR over 0.1 suggests a problem with fit (Hair et al., 2010). These three measures justify that the model is within the acceptable range of the fit, and that the estimated $\chi^{2}$ value $(p<0.01)$ may be due to the sample size of this study. The other fit indices including the RMSEA and the RMR are 0.03 and 0.02 , respectively. These results, considering the large sample size, show that the model fits the sample data set (Hair et al., 2010; Ho, 2006). The incremental fit measures including TLI, NFI, CFI are 0.99, 0.98, 0.99, respectively. The parsimonious fit measures including AGFI, PNFI, PCFI are $0.95,0.62,0.62$, respectively. Overall, these values are all within the cut-off points as suggested by the literature (Hair et al., 2010; Ho, 2006).

\begin{tabular}{lcccccccc}
\hline Constructs & Info & PE & ACSQ & ADSQ & FSQ & S & T & I \\
\hline Info & - & 0.78 & 0.82 & 0.82 & 0.75 & 0.86 & 0.82 & 0.83 \\
PE & 0.16 & - & 0.81 & 0.81 & 0.75 & 0.84 & 0.81 & 0.82 \\
ACSQ & 0.21 & 0.19 & - & 0.83 & 0.79 & 0.85 & 0.82 & 0.83 \\
ADSQ & 0.18 & 0.16 & 0.40 & - & 0.79 & 0.85 & 0.83 & 0.83 \\
FSQ & 0.21 & 0.13 & 0.33 & 0.29 & - & 0.81 & 0.79 & 0.79 \\
S & 0.20 & 0.18 & 0.50 & 0.40 & 0.33 & - & 0.84 & 0.86 \\
T & 0.31 & 0.22 & 0.56 & 0.44 & 0.37 & 0.60 & - & 0.83 \\
I & 0.34 & 0.16 & 0.39 & 0.33 & 0.27 & 0.54 & 0.58 & -
\end{tabular}

Note: The upper and lower diagonals show the AVE and the correlation coefficients between the variables, respectively

\section{Service quality}

771

Table II.

Discriminant validity test using AVE and squared correlation method 
APJML 24,5

772

Results of the structural model analyses. Figure 2 shows the structural model with standardised estimates. The results of the absolute fit measures of the full structural equation model show that the $\chi^{2}$ statistic, $\chi^{2}(n=528, \mathrm{df}=95)$ is 201.50 and the associated $p$-value is less than 0.01 . As significant $p$-value is not desirable, the results of alternative measures as suggested by several studies (Anderson and Gerbing, 1988; Hair et al., 2010; Ho, 2006) show that the normed $\chi^{2}$ is 2.12 (i.e. $\leq 3.0$ ), the SRMR is 0.02 (i.e. SRMR < 0.1) and Hoelter's critical $n$ is 208 and 228 at the 0.05 and 0.01 level. These alternative measures against $\chi^{2}$ are suggested as the associated $p$-value of the $\chi^{2}$ is less meaningful when the sample size and number of observed variables are large. In addition, the other fit indices including the RMSEA and the RMR are 0.06 and 0.29 , respectively. These results, considering the large sample size, show that the model fits the sample data set (Hair et al., 2010; Ho, 2006). The incremental fit measures including TLI, NFI, CFI are 0.96, 0.95, 0.97, respectively. The parsimonious fit measures including AGFI, PNFI, PCFI are 0.92, 0.76, 0.77, respectively. These values are all within the cut-off points as suggested by the literature (Hair et al., 2010; Ho, 2006).

Hypotheses testing results. There were six hypotheses in this study related to the causal relationships between the constructs. Table III shows the hypotheses testing results. Overall, the results suggest that five hypotheses are positive and statistically significant. The five most significant paths are $H 1$ (information determining perceived

Figure 2.

The structural model

\begin{tabular}{|c|c|c|c|}
\hline Hypotheses & Standardised regression weights & Sig. & $\begin{array}{c}\text { Supported } \\
\text { (yes/no) }\end{array}$ \\
\hline H1: information $\rightarrow$ service quality & 0.76 & $p<0.01$ & Yes \\
\hline$H 2$ : past experience $\rightarrow$ service quality & 0.09 & $p>0.05$ & No \\
\hline H3: service quality $\rightarrow$ satisfaction & 0.92 & $p<0.01$ & Yes \\
\hline$H 4:$ service quality $\rightarrow$ trust & 0.98 & $p<0.01$ & Yes \\
\hline H5: satisfaction $\rightarrow$ image & 0.52 & $p<0.01$ & Yes \\
\hline$H 6:$ trust $\rightarrow$ image & 0.42 & $p<0.01$ & Yes \\
\hline
\end{tabular}

Table III.

Hypotheses testing results

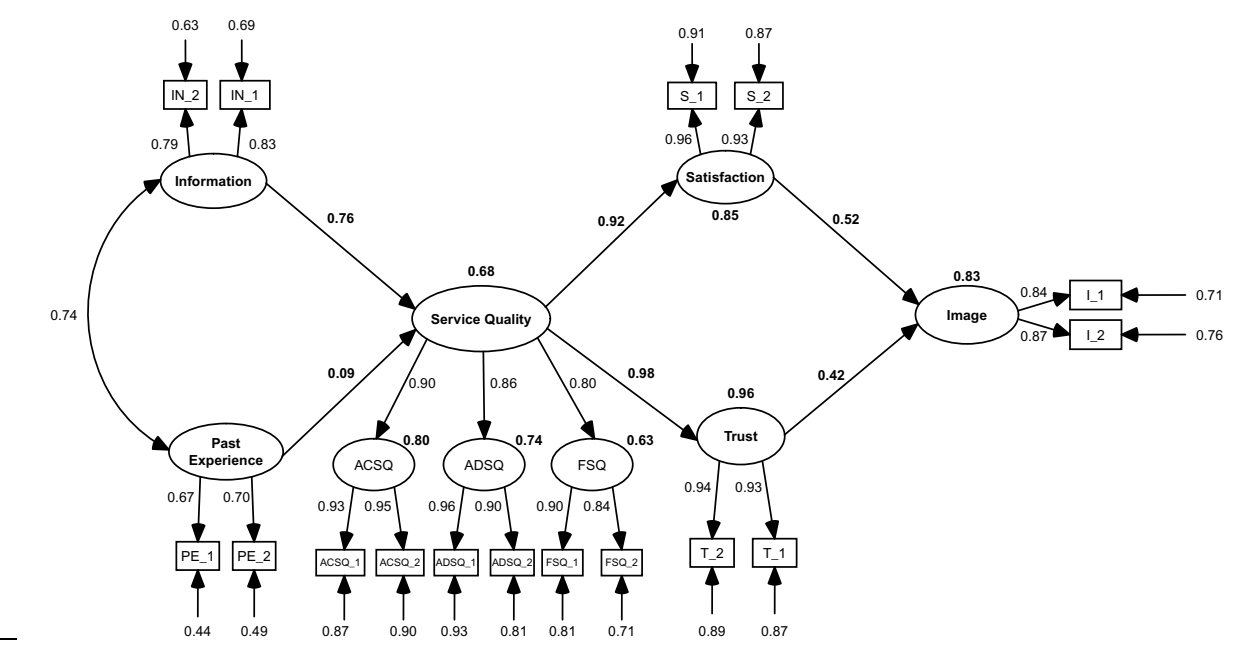


service quality), H3 (perceived service quality determining satisfaction), $H 4$ (perceived service quality determining trust), H5 (satisfaction determining image), and $H 6$ (trust determining image). The standardised path coefficients of $H 1, H 3, H 4, H 5$ and $H 6$ are $0.76,0.92,0.98,0.52$ and 0.42 , respectively, and these are significant at the 0.01 level. However, one hypothesis (H2, past experience determining perceived service quality) is positive but statistically not significant at the 0.05 level. The results also demonstrate a strong predictive ability of the latent constructs, for example, the squared multiple correlations $\left(R^{2}\right)$ of service quality, satisfaction, trust and image are $0.68,0.85,0.96$ and 0.83 , respectively, and these are significant at the 0.01 level.

\section{Discussion}

The findings of the present study suggest that information received from marketing communication is a more significant factor than past experience in terms of its affect on service quality. The present study also shows that marketing communication information can directly affect perceived service quality in a higher education context. These results confirm the essential role of information in forming perceived service quality in a higher education context.

Higher education is a pure service and requires person-to-person interaction (Oldfield and Baron, 2000). The findings of the current study show that students' past experience may have little or no impact in forming perception of quality. One of the reasons for this may be due to the fact that the CQU is a distance university and it has the largest number of off-campus students in Australia. They maintain an online or virtual contact with the university, and have limited opportunity to meet their staff and/or visit their campuses. Second, the CQU is also one of the largest universities in Australia that has ten campuses in Australia with a huge number of international students. They have various nationalities and diverse study experiences and backgrounds. These may have resulted an insignificant effect of past experience on perceived quality in this study.

There are several marketing implications of these findings. Higher education marketing managers should pay particular attention to developing a formal information structure for potential students through the promises and content of the message. The university needs to perform well in terms of marketing communication information in order to increase the perceived service quality. Information is a basis of forming quality standards as it often provides evidence of past performance. Together, with past evidence, information may play a vital role to forming quality perception. However, exaggerated information with gimmicks or ambitious promises may adversely affect quality perception during service encounters. This shows the importance of cultivating past experience aspects in terms of augmenting service quality in the higher education industry. The empirical evidence from this study suggests that service quality in a university context can be categorised into three major areas namely: academic services, administrative services, and facility services. These categories are related to specific attributes of the higher educational institution that students encounter during their studies. For example, first, the ACSQ includes the quality of lectures, interactive and entertaining lectures, after-lecture availability of lecturers for consultation, and lastly lecturers' intellectual ability and understandings of the course, the students and relevant research. Second, the ADSQ includes effective responses to students' queries, efficiency and effectiveness during admission procedures, and services relevant to the

\section{Service quality}

773 
APJML 24,5

\section{4}

overall process of administering and delivering education. Third, the FSQ includes: library facilities, IT workshops and seminars of resource staff, careers counselling, transport facilities, catering facilities and entertainment facilities. These categories can help the university to focus on their efforts and resources.

Perceived service quality can have statistically significant impact on post-experience (evaluation) aspects. The findings of this study indicate that service quality has a strong direct influence on trust and satisfaction, with standardised coefficients of 0.98 and 0.92 , respectively. It indicates that one unit increase of service quality will result in almost one unit increase in trust and satisfaction. Trust and satisfaction, in turn, were found to have impacted on university image.

Overall, the study suggests a three-tiered model that comprises pre-experience, current experience, and post-experience aspects; and establishes the important role of service quality in a higher education context. The model provides us with both theoretical and practical insights into the way service quality can be deployed in the higher education industry. The study highlights service quality as the critical element in higher education.

\section{Conclusion, limitations and future research}

This study develops a structural model incorporating the links between the antecedents and consequences of perceived service quality in a higher education context. The antecedent factor includes marketing communication information and the consequence factor comprises trust, satisfaction, and image. The model has been tested using structural equation modelling with a sample of 528 university students from various backgrounds. The results state that the theoretical model has overall validity and that all of the key paths in the model are statistically significant, except the affect of past experience on perceptions of service quality. The model provides a good explanation of developing university image. Of special significance, service quality is found to play an important role in the overall model. Universities intending to enhance their image are encouraged to consider focusing their efforts on marketing communication information and service quality.

One of the important limitations of this study is that this study finds an insignificant effect of past experience on perceived quality in the model. In particular, two of the three items (i.e. PE_1 and PE_2) of past experience construct do not refer to previous use or actual involvement with the university. Future study should provide careful attention to operationalise the past experience construct. Although selecting a single university does not enable researchers to generalise the findings to other universities (Sawyer and Thompson, 2003), inclusion of all CQU students, programs, schools and campuses in the context of the present study is a popular alternative for generating important insights about antecedents and consequences of service quality in a higher education context. Using a single university to study students' attitudes generates valuable insights, which can be used as an empirical basis for more representative follow-up studies (Dolnicar, 2004). Selecting a single university for the purpose of data collection for the present study also conforms to the current studies (Brown et al., 2009; Douglas et al., 2008; Gatfield et al., 1999; Helgesen and Nesset, 2007; Navarro et al., 2005; Oldfield and Baron, 2000; Smith et al., 2007; Stodnick and Rogers, 2008).

Future research should examine the generalisability of the measures and the model in the wider context of Australian higher education sector. Future study should examine 
and compare this model with the ECSI model in the context of higher education, and other service industries. This could provide further insights in regard to the role of service quality in relevant industries. A cross-country study may also provide interesting findings. The usability of this model in the higher education domain and its subsequent applicability in commercial settings may be of interest to some scholars. The impact of student background especially in terms of their program of study, campus, maturity (full time versus part time/flex students), level of study (undergraduate versus post graduate) may have an impact on the overall model estimation. In particular, various cohorts of students may gather past experience from various sources and cultures. For example, undergraduate students may gather past experience from high schools that they attended in their countries, their recent visits to the current university, open day, career fair and the like. Similarly, distance and/or flexible and mature students may gather past experience from their local centres/campuses, previous study background and learning experience with other institutions and the like. These sources may not have a direct relationship with what they have experienced in the university where they are studying. Thus, further research could shed lights on these issues. Future study should also include a large sample size as this could have an overall impact on the model estimation. Finally, a longitudinal study could also be a valuable contribution to the service quality literature.

\section{References}

Abdullah, F. (2005), "HEdPERF versus SERVPERF: the quest for ideal measuring instrument of service quality in higher education sector", Quality Assurance in Education, Vol. 13 No. 4, pp. 305-28.

Abdullah, F. (2006a), "Measuring service quality in higher education: HEdPERF versus SERVPERF", Marketing Intelligence \& Planning, Vol. 24 No. 1, pp. 31-47.

Abdullah, F. (2006b), "Measuring service quality in higher education: three instruments compared", International Journal of Research and Method in Education, Vol. 29 No. 1, pp. 71-89.

Abdullah, F. (2006c), "The development of HEdPERF: a new measuring instrument of service quality for the higher education sector", International Journal of Consumer Studies, Vol. 30 No. 6, pp. 569-81.

Abratt, R. (1989), “A new approach to the corporate image management process", Journal of Marketing Management, Vol. 5 No. 1, pp. 63-76.

Alves, H. and Raposo, M. (2007), "Conceptual model of student satisfaction in higher education”, Total Quality Management, Vol. 18 No. 5, pp. 571-88.

Anderson, J. and Gerbing, D. (1988), "Structural equation modeling in practice: a review and recommended two-step approach”, Psychological Bulletin, Vol. 103 No. 3, pp. 411-23.

Andreassen, T. and Lindestad, B. (1998), "The impact of corporate image on quality, customer satisfaction and loyalty for customers with varying degrees of service expertise", International Journal of Service Industry Management, Vol. 9 No. 1, pp. 7-23.

Angell, R.J., Heffernan, T.W. and Megicks, P. (2008), "Service quality in postgraduate education", Quality Assurance in Education, Vol. 16 No. 3, pp. 236-54.

Babakus, E. and Boller, G.W. (1992), “An empirical assessment of the SERVQUAL scale”, Journal of Business Research, Vol. 24 No. 3, pp. 253-68.

Babbie, E. (2007), The Practice of Social Research, Wadsworth, Belmont, CA. 
APJML 24,5
Bandalos, D.L. (2002), "The effects of item parceling on goodness-of-fit and parameter estimate bias in structural equation modeling", Structural Equation Modeling: A Multidisciplinary Journal, Vol. 9 No. 1, pp. 78-102.

Bentler, P. and Chou, C. (1987), "Practical issues in structural modeling", Sociological Methods \& Research, Vol. 16 No. 1, pp. 78-117.

Bernstein, D. (1984), Company Image and Reality: A Critique of Corporate Communications, Holt Rinehart and Winston, Eastbourne.

Berry, L.L. (2002), "Relationship marketing of services - perspectives from 1983 and 2000", Journal of Relationship Marketing, Vol. 1 No. 1, pp. 59-77.

Bethlehem, J. (2010), "Selection bias in web surveys", International Statistical Review, Vol. 78 No. 2, pp. 161-88.

Biedenbach, G. and Marell, A. (2010), "The impact of customer experience on brand equity in a business-to-business services setting", Brand Management, Vol. 17 No. 6, pp. 446-58.

Bitner, M.J. (1990), "Evaluating service encounters: the effects of physical surroundings and employee responses", Journal of Marketing, Vol. 54 No. 2, pp. $69-82$.

Blythe, J. (1997), The Essence of Consumer Behaviour, Prentice-Hall, London.

Bolton, R. and Drew, J. (1991), "A longitudinal analysis of the impact of service changes on customer attitudes", Journal of Marketing, Vol. 55 No. 1, pp. 1-9.

Bradley, D., Noonan, P., Nugent, H. and Scales, B. (2008), Review of Australian Higher Education, Department of Education, Employment and Workplace Relations, Canberra.

Brady, M.K., Cronin, J.J. and Brand, R.R. (2002), "Performance-only measurement of service quality: a replication and extension", Journal of Business Research, Vol. 55 No. 1, pp. 17-31.

Brown, C., Varley, P. and Pal, J. (2009), "University course selection and services marketing", Marketing Intelligence \& Planning, Vol. 27 No. 3, pp. 310-25.

Brown, R. and Mazzarol, T. (2009), "The importance of institutional image to student satisfaction and loyalty within higher education", Higher Education, Vol. 58, pp. 81-95.

Brown, T.J., Churchill, G.A. and Peter, J.P. (1993), "Improving the measurement of service quality”, Journal of Retailing, Vol. 69 No. 1, pp. 127-39.

Bruin, G.P. (2004), "Problems with the factor analysis of items: solutions based on item response theory and item parcelling", Journal of Industrial Psychology, Vol. 30 No. 4, pp. 16-26.

Bryman, A. and Bell, E. (2007), Business Research Methods, Oxford University Press, Oxford.

Carlson, J. and O'Cass, A. (2010), "Exploring the relationships between e-service quality, satisfaction, attitudes and behaviours in content-driven e-service web sites", Journal of Services Marketing, Vol. 24 No. 2, pp. 112-27.

Carrillat, F.A., Jaramillo, F. and Mulki, J.P. (2007), "The validity of the SERVQUAL and SERVPERF scales - a meta-analytic view of 17 years of research across five continents", International Journal of Service Industry Management, Vol. 18 No. 5, pp. 472-90.

Cassel, C. and Eklöf, J.A. (2001), "Modelling consumer satisfaction and loyalty on aggregate levels: experience from the ECSI pilot study", Total Quality Management, Vol. 12 Nos 7/8, pp. 834-41.

Chaudhuri, A. and Holbrook, M.B. (2001), "The chain of effects from brand trust and brand affect to brand performance: the role of brand loyalty", Journal of Marketing, Vol. 65 No. 2, pp. 81-93. 
Chebat, J.C., Filiatrault, P., Gelinas-Chebat, C. and Vaninsky, A. (1995), "Impact of waiting attribution and consumer's mood on perceived quality", Journal of Business Research, Vol. 34 No. 3, pp. 191-6.

Chitty, B. and Soutar, G.N. (2004), "Is the European customer satisfaction index model applicable to tertiary education?", Proceedings of the Australian and New Zealand Marketing Academy Conference.

Churchill, G.A. (1979), "A paradigm for developing better measures of marketing constructs”, Journal of Marketing, Vol. 16 No. 2, pp. 64-73.

Cronin, J. and Taylor, S. (1992), "Measuring service quality: a re-examination and extension", Journal of Marketing, Vol. 56 No. 3, pp. 55-68.

Cronin, J. and Taylor, S. (1994), "SERVPERF versus SERVQUAL: reconciling performance-based and perceptions-minus-expectations measurement of service quality", Journal of Marketing, Vol. 58 No. 1, pp. 125-31.

Cronin, J., Brady, M. and Hult, G. (2000), "Assessing the effect of quality, value, and customer satisfaction on consumer behavioral intentions in service environments", Journal of Retailing, Vol. 76 No. 2, pp. 193-218.

Dabholkar, P.A., Shepherd, C.D. and Thorpe, D.I. (2000), "A comprehensive framework for service quality: an investigation of critical conceptual and measurement issues through a longitudinal study", Journal of Retailing, Vol. 76 No. 2, pp. 139-73.

Dahlstrom, R., Nygaard, A. and Crosno, J. (2008), "Strategic, metric and methodological trends in marketing research and their implications for future theory and practice", Journal of Marketing Theory and Practice, Vol. 16 No. 2, pp. 139-52.

Deighton, J. (1984), "The interaction of advertising and evidence”, Journal of Consumer Research, Vol. 11 No. 3, pp. 763-70.

Delgado-Ballester, E. and Munuera-Aleman, J.L. (2001), "Brand trust in the context of consumer loyalty”, European Journal of Marketing, Vol. 35 Nos 11/12, pp. 1238-58.

Delgado-Ballester, E. and Munuera-Aleman, J.L. (2005), "Does brand trust matter to brand equity?", Journal of Product and Brand Management, Vol. 14 Nos 2/3, pp. 187-96.

Deshpande, R. (1983), "Paradigms lost: on theory and method in research in marketing", Journal of Marketing, Vol. 47, Fall, pp. 101-10.

De Vaus, D.A. (2001), Research Design in Social Research, Sage, London.

Devlin, J.F., Gwynne, A.L. and Ennew, C.T. (2002), "The antecedents of service expectations", The Service Industries Journal, Vol. 22 No. 4, pp. 117-36.

Dillman, D.A., Smyth, J.D. and Christian, L.M. (2009), Internet, Mail and Mixed-Mode Surveys: The Tailored Design Method, Wiley, Hoboken, NJ.

Dolnicar, S. (2004), "What makes students attend lectures? The shift towards pragmatism in undergraduate lecture attendance", Proceedings of the Australian and New Zealand Marketing Academy Conference, Wellington, New Zealand, 29 November-1 December.

Donaldson, B. and McNicholas, C. (2004), "Understanding the postgraduate education market for UK-based students: a review and empirical study", International Journal of Nonprofit and Voluntary Sector Marketing, Vol. 9 No. 4, pp. 346-60.

Douglas, J., McClelland, R. and Davies, J. (2008), "The development of a conceptual model of student satisfaction with their experience in higher education", Quality Assurance in Education, Vol. 16 No. 1, pp. 19-35.

Dowling, G. (1993), "Developing your company image into a corporate asset", Long Range Planning, Vol. 26 No. 2, pp. 101-9. 
APJML 24,5
Eskildsen, J., Kristensen, K., Juhl, H.J. and Østergaard, P. (2004), "The drivers of customer satisfaction and loyalty: the case of Denmark 2000-2002", Total Quality Management, Vol. 15 Nos 5/6, pp. 859-68.

Fornell, C. (1992), "A national customer satisfaction barometer: the Swedish experience", Journal of Marketing, Vol. 56 No. 1, pp. 6-21.

Fornell, C. and Larcker, D.F. (1981), "Evaluating structural equation models with unobservable variables and measurement errors", Journal of Marketing Research, Vol. 18 No. 1, pp. 39-50.

Fornell, C., Johnson, M.D., Anderson, E.W., Cha, J. and Bryant, B.E. (1996), "The American customer satisfaction index: nature, purpose and findings", Journal of Marketing, Vol. 60 No. 4, pp. 7-18.

Freling, T.H. and Forbes, L. (2005), "An examination of brand personality through methodological triangulation”, Journal of Brand Management, Vol. 13 No. 2, pp. 148-62.

Furrer, O., Liu, B.S. and Sudharshan, D. (2000), "The relationships between culture and service quality perceptions", Journal of Service Research, Vol. 2 No. 4, pp. 355-71.

Gallifa, J. and Batalle, P. (2010), "Student perceptions of service quality in a multi-campus higher education system in Spain”, Quality Assurance in Education, Vol. 18 No. 2, pp. 156-70.

Gatfield, T., Barker, M. and Graham, P. (1999), "Measuring student quality variables and the implications for management practices in higher education institutions: an Australian and international student perspective", Journal of Higher Education Policy and Management, Vol. 21 No. 2, pp. 239-52.

Ghosh, A.K., Whipple, T.W. and Bryan, G.A. (2001), "Student trust and its antecedents in higher education", The Journal of Higher Education, Vol. 72 No. 3, pp. 322-40.

Gounaris, S., Dimitriadis, S. and Stathakopoulos, V. (2010), "An examination of the effects of service quality and satisfaction on customers' behavioural intentions in e-shopping", Journal of Services Marketing, Vol. 24 No. 2, pp. 142-56.

Grönroos, C. (1984), “A service quality model and its marketing implications", European Journal of Marketing, Vol. 18 No. 4, pp. 36-44.

Hair, J.F., Black, W.C., Babin, B.J. and Anderson, R.E. (2010), Multivariate Data Analysis: A Global Perspective, Prentice-Hall, New York, NY.

Hall, R.J., Snell, A.F. and Foust, M.S. (1999), "Item parceling strategies in SEM: investigating the subtle effects of unmodeled secondary constructs", Organisational Research Methods, Vol. 2 No. 3, pp. 233-56.

Hau, K. and Marsh, H.W. (2004), "The use of item parcels in structural equation modelling: non-normal data and small sample size", British Journal of Mathematical Statistical Psychology, Vol. 57 No. 2, pp. 327-51.

Helgesen, Ø. and Nesset, E. (2007), "What accounts for students' loyalty? Some field study evidence", International Journal of Educational Management Decision, Vol. 21 No. 2, pp. 126-43.

Hennig-Thurau, T., Langer, M.F. and Hansen, U. (2001), "Modeling and managing student loyalty: an approach based on the concept of relationship quality", Journal of Service Research, Vol. 3 No. 4, pp. 331-44.

Ho, R. (2006), Handbook of Univariate and Multivariate Data Analysis and Interpretation with SPSS, Taylor \& Francis, New York, NY.

Hoch, S.J. and Deighton, J. (1989), "Managing what consumers learn from experience", Journal of Marketing, Vol. 53 No. 2, pp. 1-20. 
Hoelter, J.W. (1983), "The analysis of covariance structures: goodness-of-fit indices", Sociological Methods \& Research, Vol. 11, pp. 325-44.

Horppu, M., Kuivalainen, O., Tarkiainen, A. and Ellonen, H. (2008), “Online satisfaction, trust and loyalty, and the impact of the offline parent brand", Journal of Product and Brand Management, Vol. 17 No. 6, pp. 403-13.

Hu, H., Kandampully, J. and Juwaheer, T.D. (2009), "Relationships and impacts of service quality, perceived value, customer satisfaction, and image: an empirical study", The Services Industries Journals, Vol. 29 No. 2, pp. 111-25.

Jain, S.K. and Gupta, G. (2004), "Measuring service quality: SERVQUAL vs SERVPERF scales", Vikalpa, Vol. 29 No. 2, pp. 25-37.

Johnson, M., Gustafsson, A., Andreassen, T., Lervik, L. and Cha, J. (2001), "The evolution and future of national customer satisfaction index models", Journal of Economic Psychology, Vol. 22 No. 2, pp. 217-45.

Johnson, R. and Winchell, W. (1988), "Educating for quality”, Quality Progress, Vol. 2 No. 1, pp. 48-50.

Joseph, M. and Joseph, B. (1997), "Service quality in education: a student perspective", Quality Assurance in Education, Vol. 5 No. 1, pp. 15-19.

Kandampully, J. and Suhartanto, D. (2000), "Customer loyalty in the hotel industry: the role of customer satisfaction and image", International Journal of Contemporary Hospitality Management, Vol. 12 No. 6, pp. 346-51.

Krippendorff, K. (2004), Content Analysis: An Introduction to Its Methodology, Sage, London.

Krueger, R.A. and Casey, M.A. (2000), Focus Groups: A Practical Guide for Applied Research, Sage, London.

Kwan, P.Y.K. and Ng, P.W.K. (1999), "Quality indicators in higher education: comparing Hong Kong and China's students”, Managerial Auditing Journal, Vol. 14, pp. 20-7.

Landis, R.S., Beal, D.J. and Tesluk, P.E. (2000), "A comparison of approaches to forming composite measures in structural equation models", Organisational Research Methods, Vol. 3 No. 2, pp. 186-207.

Lau, G.T. and Lee, S.H. (2000), "Consumer's trust in a brand and the link to brand loyalty", Journal of Market Focused Management, Vol. 4 No. 4, pp. 341-70.

LeBlanc, G. and Nguyen, N. (1996), "Cues used by customers evaluating corporate image in service firms, an empirical study in financial institutions", International Journal of Service Industry Management, Vol. 7 No. 2, pp. 44-56.

LeBlanc, G. and Nguyen, N. (1997), "Searching for excellence in business education: an exploratory study of customer impressions of service quality", International Journal of Educational Management, Vol. 11 No. 2, pp. 72-9.

Li, R.Y. and Kaye, M. (1998), "A case study for comparing two service quality measurement approaches in the context of teaching in higher education", Quality in Higher Education, Vol. 4 No. 2, pp. 103-13.

Liew, J. (1997), "Banking on a sharper image", Corporate Communications: An International Journal, Vol. 2 No. 2, pp. 76-86.

Little, T.D., Cunningham, W.A., Shahar, G. and Widaman, K.F. (2002), "To parcel or not to parcel: exploring the question, weighing the merits", Structural Equation Modeling: A Multidisciplinary Journal, Vol. 9 No. 2, pp. 151-73.

Martensen, A., Grønholdt, L., Eskildsen, J.K. and Kristensen, K. (2000), "Measuring student oriented quality in higher education: application of the ECSI methodology", Proceedings of the Higher Education Institutions and the Issue of Total Quality Conference, available at: www.blweb.it/esoe/tqmhe2/29.pdf 
APJML 24,5
Mathews, B.P. (1994), "Modelling the antecedents of service expectations", Proceedings of the MEG Annual Conference, University of Ulster, Belfast.

Morgan, D.L. (1988), Focus Groups as Qualitative Research, Sage, London.

Navarro, M.M., Iglesias, M.P. and Torres, P.R. (2005), "A new management element for universities: satisfaction with the offered courses", The International Journal of Educational Management, Vol. 19 Nos 6/7, pp. 505-26.

Neuendorf, K.A. (2005), The Content Analysis Guidebook, Sage, London.

Nguyen, N. and LeBlanc, G. (1998), "The mediating role of corporate image on customers' retention decisions: an investigation in financial services", International Journal of Bank Marketing, Vol. 16 No. 2, pp. 52-65.

Nguyen, N. and Leblanc, G. (2001), “Corporate image and corporate reputation in customers' retention decisions in services", Journal of Retailing and Consumer Services, Vol. 8 No. 1, pp. 227-36.

Oldfield, B.M. and Baron, S. (2000), "Student perceptions of service quality in a UK university business and management faculty", Quality Assurance in Education, Vol. 8 No. 2, pp. 85-95.

O'Leary-Kelly, S.W. and Vokurka, R.J. (1998), "The empirical assessment of construct validity", Journal of Operations Management, Vol. 16 No. 4, pp. 387-405.

O'Neill, M. and Palmer, A. (2003), “An exploratory study of the effects of experience on consumer perceptions of the service quality construct”, Managing Service Quality, Vol. 13 No. 3, pp. 187-96.

Parasuraman, A., Zeithaml, V.A. and Berry, L.L. (1985), “A conceptual model of service quality and its implications for future research", Journal of Marketing, Vol. 49 No. 4, pp. 41-50.

Parasuraman, A., Zeithaml, V.A. and Berry, L.L. (1988), "SERVQUAL: a multiple-item scale for measuring consumer perceptions of service quality", Journal of Retailing, Vol. 64 No. 1, pp. 12-40.

Parasuraman, A., Zeithaml, V.A. and Berry, L.L. (1994), "Reassessment of expectations as a comparison standard in measuring service quality: implications for further research", Journal of Marketing, Vol. 58 No. 1, pp. 111-24.

Punch, K.F. (2005), Introduction to Social Research: Quantitative and Qualitative Approaches, Sage, London.

Rojas-Méndez, J.I., Vasquez-Parraga, A.Z., Kara, A. and Cerda-Urrutia, A. (2009), "Determinants of student loyalty in higher education: a tested relationship approach in Latin America", Latin American Business Review, Vol. 10, pp. 21-39.

Rowley, J. (1997), "Beyond service quality dimensions in higher education and towards a service contract”, Quality Assurance in Education, Vol. 5 No. 1, pp. 7-14.

Sarantakos, S. (1997), Social Research, Macmillan Education Australia Pty Ltd, Melbourne.

Sawyer, R.G. and Thompson, E. (2003), "Knowledge and attitudes about emergency contraception in university students", College Student Journal, Vol. 37 No. 4, pp. 523-9.

Sax, L.J., Gilmartin, S.K. and Bryant, A.N. (2003), "Assessing response rates and nonresponse bias in web and paper surveys", Research in Higher Education, Vol. 44 No. 4, pp. 409-32.

Smith, G., Smith, A. and Clarke, A. (2007), "Evaluating service quality in universities: a service department perspective", Quality Assurance in Education, Vol. 15 No. 3, pp. 334-51. 
Stavros, C. and Westberg, K. (2009), "Using triangulation and multiple case studies to advance relationship marketing theory", Qualitative Market Research: An International Journal, Vol. 12 No. 3, pp. 307-20.

Stewart, D.W., Shamdasani, P.N. and Rook, D.W. (2007), Focus Groups: Theory and Practice, Sage, London.

Stodnick, M. and Rogers, P. (2008), "Using SERVQUAL to measure the quality of the classroom experience”, Decision Sciences Journal of Innovative Education, Vol. 6 No. 1, pp. 115-33.

Sultan, P. and Wong, H.Y. (2010a), "Performance-based service quality model: an empirical study on Japanese universities", Quality Assurance in Education, Vol. 18 No. 2, pp. 126-43.

Sultan, P. and Wong, H.Y. (2010b), "Service quality in higher education: a review and research agenda", International Journal of Quality and Service Sciences, Vol. 2 No. 2, pp. 259-72.

Sumaedi, S., Bakti, G. and Metasari, N. (2012), "An empirical study of state university students' perceived service quality”, Quality Assurance in Education, Vol. 20 No. 2, pp. 164-83.

Topalian, A. (1984), "Corporate identity: beyond the visual overstatements", International Journal of Advertising Research, Vol. 3 No. 1, pp. 55-62.

Wong, H.Y. and Merrilees, B. (2007), "Multiple roles for branding in international marketing", International Marketing Review, Vol. 24 No. 4, pp. 384-408.

Zboja, J.J. and Voorkees, C.M. (2006), "The impact of brand trust and satisfaction on retailer purchase intentions", Journal of Services Marketing, Vol. 20 No. 6, pp. 381-90.

Zeithaml, V.A. and Bitner, M.J. (2003), Services Marketing: Integrating Customer Focus Across the Firm, Irwin McGraw-Hill, Boston, MA.

Zeithaml, V.A., Berry, L.L. and Parasuraman, A. (1993), "The nature and determinants of customer expectations of service", Journal of the Academy of Marketing Science, Vol. 21 No. 1, pp. 1-12.

Zeithaml, V.A., Berry, L.L. and Parasuraman, A. (1996), "The bahavioral consequences of service quality", Journal of Marketing, Vol. 60 No. 2, pp. 31-46.

Zhou, L. (2004), "A dimension-specific analysis of performance-only measurement of service quality and satisfaction in china's retail banking", The Journal of Services Marketing, Vol. 18 Nos 6/7, pp. 534-46.

\section{Further reading}

Boulding, W., Kalra, A., Staelin, R. and Zeithaml, V.A. (1993), "A dynamic process model of service quality: from expectations to behavioural intentions", Journal of Marketing Research, Vol. 30 No. 1, pp. 7-27.

ECSI (1998), European Customer Satisfaction Index: Foundation and Structure for Harmonized National Pilot Projects, report prepared for the ECSI Technical Committee, October.

Grönroos, C. (1993), "Toward a third phase in service quality research: challenges and future directions", in Swartz, T.A., Bowen, D.E. and Brown, S.W. (Eds), Advances in Services Marketing and Management, Vol. 2, JAI Press, Greenwich, CT, pp. 49-64.

Yuksel, A. and Yuksel, F. (2001), “The expectancy-disconfirmation paradigm: a critique”, Journal of Hospitality \& Tourism Research, Vol. 25 No. 2, pp. 107-31. 
APJML
24,5

782

Table AI.

Service quality

dimensions in higher education

\section{Appendix 1}

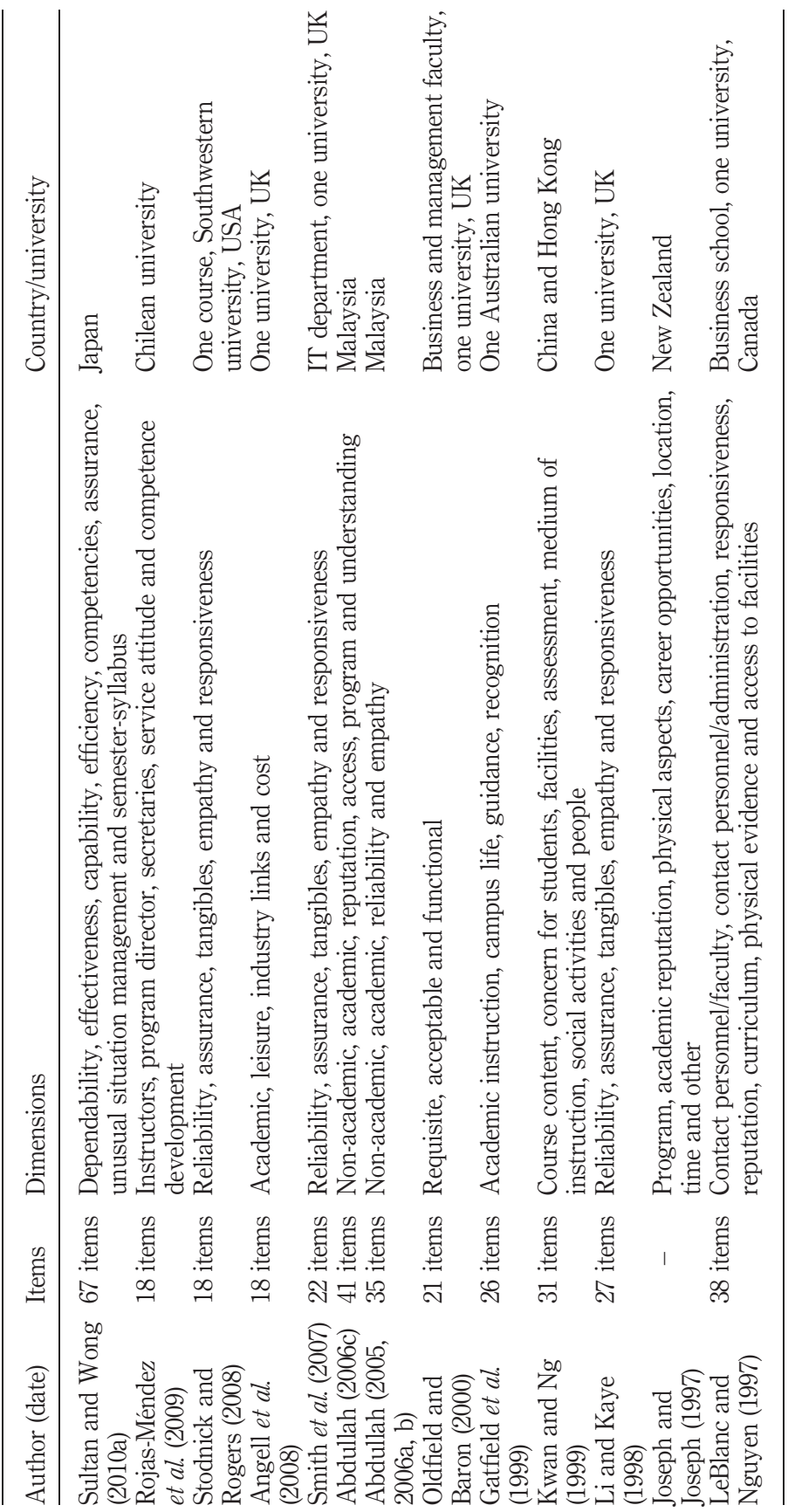




\section{Appendix 2}

\begin{tabular}{|c|c|c|}
\hline $\begin{array}{l}\text { Author } \\
\text { (date) }\end{array}$ & $\begin{array}{l}\text { Key constructs: affect variables - } \\
\text { service quality - effect variables }\end{array}$ & Major aspects \\
\hline Brown and & \multirow{2}{*}{$\begin{array}{l}\text { Image, service quality - value - } \\
\text { satisfaction, loyalty }\end{array}$} & Empirically examined the model with students of four \\
\hline $\begin{array}{l}\text { Mazzarol } \\
(2009)\end{array}$ & & $\begin{array}{l}\text { Australian universities, the ECSI model was the basic } \\
\text { skeleton, service quality has no effect on value, } \\
\text { satisfaction and loyalty }\end{array}$ \\
\hline Rojas- & \multirow{2}{*}{$\begin{array}{l}\text { Service quality - satisfaction - } \\
\text { trust - commitment - loyalty }\end{array}$} & Empirically examined the model with students of one \\
\hline $\begin{array}{l}\text { Méndez } \\
\text { et al. }(2009)\end{array}$ & & $\begin{array}{l}\text { Latin American university; the causal relationships } \\
\text { between constructs are in the form of a straight line }\end{array}$ \\
\hline Alves and & \multirow{2}{*}{$\begin{array}{l}\text { Image, expectation - service } \\
\text { quality - value, satisfaction, } \\
\text { word-of-mouth, loyalty }\end{array}$} & Empirically examined the model with students of 13 \\
\hline $\begin{array}{l}\text { Raposo } \\
(2007)\end{array}$ & & $\begin{array}{l}\text { Portuguese state universities, the ECSI model was the } \\
\text { basic skeleton, expectation has a significant and } \\
\text { negative path relationship with satisfaction }\end{array}$ \\
\hline $\begin{array}{l}\text { Helgesen } \\
\text { and Nesset } \\
(2007)\end{array}$ & $\begin{array}{l}\text { Service quality - satisfaction, } \\
\text { reputation, loyalty }\end{array}$ & $\begin{array}{l}\text { Empirically examined the model with undergraduate } \\
\text { students of one Norwegian university, Cronbach's } \alpha \\
\text { coefficients for a number of constructs are low }\end{array}$ \\
\hline Navarro & Quality aspects - student & Empirically examined the model with students of one \\
\hline et al. (2005) & satisfaction - student loyalty & $\begin{array}{l}\text { Spanish university, single item measures (e.g. } \\
\text { satisfaction, infrastructure) are used, spurious } \\
\text { relationships between a dimension and an item of } \\
\text { loyalty construct }\end{array}$ \\
\hline $\begin{array}{l}\text { Hennig- } \\
\text { Thurau }\end{array}$ & $\begin{array}{l}\text { Service quality - trust, } \\
\text { commitment, commitment, }\end{array}$ & $\begin{array}{l}\text { Empirically examined the model with former students } \\
\text { of four German universities }\end{array}$ \\
\hline
\end{tabular}

\section{Service quality}

783

Table AII. Integrated models of service quality in the context of higher education

et al. (2001) student loyalty

\section{Appendix 3}

No. Age Gender Nationality Level of study Program of study Duration of study at the CQU

1. 19 Female Japan Undergraduate Arts

2. 20 Male Australia Undergraduate Information technology

3. 20 Male Australia

4. 21 Male Australia

5. 21 Male Australia

6. 26 Male

7. 26 Male

8. 26 Male

9. 27 Male

10. 27 Male

11. 27 Male

Australia

China

China

India

India

India

12. 33 Female Singapore

13. 34 Female Australia

33 Female Bangladesh Doctoral

15. 34 Male Bangladesh Doctoral

16. 34 Male Pakistan Doctoral

17. 38 Male Botswana Doctoral

18. 37 Female China Doctoral

19. 38 Male Pakistan Doctoral ergraduate Business studies

Master's

Master's

Master's

Master's

Master's

Master's
Information technology

Business studies

Business studies

Business studies

Business studies

Business studies

Business studies

Business studies

Business studies

Education

Accounting

Law

Accounting

Information technology

Information technology
7 months

10 months

9 months

9 months

10 months

7 months

7 months

7 months

7 months

7 months

7 months

7 months

7 months

6 months

7 months

7 months

$>3$ years

$>1$ year

$>3$ years
Table AIII.

Demographics of the focus group participants 


\section{APJML 24,5}

784

\section{About the authors}

Dr Parves Sultan is a Senior Lecturer in Marketing at the Central Queensland University, Australia. Prior to this, he was an Assistant Professor at the University of Canberra, Australia. His research interests include: marketing approach to higher education, services marketing, social/sustainable marketing, tourism marketing, consumer behaviour, branding, marketing promotions, internationalisation of firms, international trade, and qualitative and quantitative research methods. His research articles appeared in a number of scholarly journals. Among these, Quality Assurance in Education, International Journal of Quality and Service Sciences, International Review of Business Research Papers, Journal for Global Business Advancement, Journal of Business Administration, Journal of Business Studies, Indian Journal of Open Learning, Malaysian Journal of Distance Education, Ritsumeikan Journal of Asia Pacific Studies, The Global Journal of Finance and Economics and Journal of Economic Cooperation are worth mentioning. Parves Sultan is the corresponding author and can be contacted at: p.sultan@cqu.edu.au

Dr Ho Yin Wong is a Senior Lecturer in Marketing at the Deakin Graduate School of Business, Deakin University, Australia. He worked as a Senior Lecturer at the Central Queensland University, Australia. His research interests include quantitative and qualitative research in marketing, branding, and international marketing. His research articles appeared in a number of scholarly journals. Among these Journal of Product and Brand Management, Journal of Strategic Marketing, International Marketing Review, International Journal of Business and Management, International Journal of Entrepreneurship and Small Business, Journal of Global Marketing, International Journal of Trade and Global Markets, Journal for International Business and Entrepreneurship Development, International Journal of Quality and Service Sciences and Quality Assurance in Education are worth mentioning.

To purchase reprints of this article please e-mail: reprints@emeraldinsight.com Or visit our web site for further details: www.emeraldinsight.com/reprints 